\title{
ALTERNATIVE MEANS OF RESOLVING TAX DISPUTES IN UKRAINE: POSSIBLE WAYS OF IMPLEMENTATION
}

\author{
Andrii Lohvyn ${ }^{1}$
}

DOI: https://doi.org/10.30525/978-9934-26-021-6-25

Abstract. Legal disputes are inseparable part of the life of society. The task of the state is to create conditions for resolving disputes and to defend the rights and interests of citizens that are protected by law. Legal relationships are undoubtedly the sphere of potential disputes. The search for alternative and effective procedures of resolving such disputes is an important issue. At the same time, the main legal issue of the tax sphere is mainly to define and effectively ensure the limits of freedom and necessity in the behavior of taxpayers through the relevant legal, legislative norms, protection of property rights of individual taxpayers and the interests of society. Alternative Dispute Resolution aбо ADR include mediation, which gained broad recognition all over the world, including the European Union, which is postulated at the legislative level. It is often used, which makes it possible to prevent the negative consequences for the dispute parties as early as at the initial stage and avoid the expensive and lengthy trial. It gained recognition in resolving a wide range of disputes and arguments, beginning with the disputes in local communities and finishing with complex multi-lateral disputes in the commercial and public spheres. In many countries it is legislatively stipulated. Today, the institution of the alternative dispute resolution in the modified form is partially present in the Ukrainian legislation and in practice, at the same time, it is difficult to call the sphere of the alternative methods of dispute resolution well-developed. In this case, the lawyers and scientists discuss a wide implementation of the alternative ways, including mediation, virtually in all branches of law. The article, taking into account the practice of using alternative dispute resolution in other countries (international experience), identifies the possibility of using them in Ukraine as a separate permanent institution of pre-trial dispute resolution in the field of tax relations (the result of

\footnotetext{
${ }^{1} \mathrm{PhD}$ in Law, University of Customs and Finance, Ukraine
} ORCID: http://orcid.org/0000-0003-4373-375X 
application of which can be achievement of reconciliation and/or tax compromise), which is directed at the improvement of tax administration. The concept of the tax compromise was also formulated and scientifically substantiated conclusions in the stated area were made.

\section{Introduction}

Alternative Dispute Resolution aбо ADR include mediation, which gained broad recognition all over the world, including the European Union, which is postulated at the legislative level $[1 ; 2]$. In general, it is considered as a voluntary will of parties to involve the third party with the aim of independent resolution of a dispute that arose, during which a mediator remains unbiased his own and keeps confidentiality of information. It is often used, which makes it possible to prevent the negative consequences for the dispute parties as early as at the initial stage and avoid the expensive and lengthy trial.

Signing the Agreement of Association [3] by Ukraine and the European Union (the US) makes Ukraine develop the problem of application of the similar methods (in particular, mediation) in the legal practice. The implementation of the alternative procedures of dispute resolution, including mediation, was added to the Plan of actions on the implementation of best practices of high-quality and effective regulation, reflected by the World bank group in the methodology of rating "Doing business", approved by the Direction of the Cabinet of Ministers of Ukraine [4].

Considering rather broad importance attached to the implementation of the procedures of alternative dispute resolution, there is a need for further scientific research into this matter.

The issues of studying and implementation in Ukraine of alternative ways of dispute resolution (including tax disputes), were explored in the research and publications of such scientists and specialists, as Y. Berdesh, V. Balukh, S. Biluga, T. Goloyadova, G. Yeremenko, Z. Krasylovska, V. Kudriavtsev, V. Kurylo, A. Ogrenchuk, S. Parkhomenko-Tsyrotsyians, L. Tsereteli, L. Yukhtenko, etc.

Legal disputes are the inseparable part of the life of society. The task of the state is to create the conditions for resolving disputes and protecting the rights and interests of the citizens defended by law. Legal relations undoubtedly are the spheres of potential disputes. The search for the alternative and 
effective procedures for resolving such disputes is an important issue. In addition, the major legal problem of the tax area is largely to determine and effectively ensure the limits of freedom and necessity in the behavior of entities of tax legal relations through the correspondent legal, legislative norms in the protection of the right of property of individual payers and the interests of the society, which are implemented in the financial and tax activity of the state.

In the article, based on the practice of the application of alternative ways of dispute resolution in other countries (international experience), we analyzed the possibility of their application in Ukraine as a separate constantly functioning institution of the pre-trial dispute resolution in the sphere of tax relations (the result of application of which can be the achievement of reconciliation and /or tax compromise), which is aimed at the improvement of tax administration, formulated the concept of the tax compromise and made scientifically substantiated conclusions on the outlined problem.

\section{Presentation of the basic material}

\subsection{Alternative dispute resolution: Draft Mediation Act}

Mediation as an alternative way of dispute resolution is widely applied all over the world, first of all, in the United States, Australia and Europe, since it is one of the most effective and least costly (first of all, in the financial aspect) ways of dispute resolution. It gained recognition in resolving a wide range of disputes and arguments, beginning with the disputes in local communities and finishing with complex multi-lateral disputes in the commercial and public spheres. In many countries it is legislatively stipulated. In such countries, as Belgium, Holland and Germany, the culture of mediation as a possible way of dispute resolution was formed, while in other countries, in particular, in Latvia, it began to function only since 2015. In Poland, the issue of introducing tax mediation is currently being considered [5].

Today, the institution of the alternative dispute resolution in the modified form is partially present in the Ukrainian legislation $[6 ; 7 ; 8]$ and in practice, at the same time, it is difficult to call the sphere of the alternative methods of dispute resolution well-developed. In this case, the lawyers and scientists discuss a wide implementation of the alternative ways, including mediation, virtually in all branches of law. 
Adoption of the Draft Law on Mediation (hereinafter - Draft Law No. 3665) [9] as the basis by the Verkhovna Rada of Ukraine in November 2016 implied certain changes in this direction. However, within three years, it was adopted only in the first reading. In February 2019, consideration of Draft Law No. 3665 was initially postponed and subsequently not adopted.

In February 2020, the Verkhovna Rada of Ukraine adopted the new draft law On Mediation (hereinafter - Draft Law No. 2706) [10]. However, this Daft Law was withdrawn in March of the same year.

Instead, in May, the Verkhovna Rada of Ukraine adopted a new draft law On Mediation (hereinafter - Draft Law No. 3405) [11]. This Draft Law has undergone some amendments compared to its predecessors. At the same time, the indicated Draft Law, like the previous ones, does not provide a full answer to some questions. In particular, this concerns the procedure of creation (registration) and the activities of organizations (associations) of mediators; formation of a qualification commission that will evaluate activities of mediators; determining professional requirements for mediators; possibility of application in tax disputes, etc. In addition, the specified Draft Law, unlike its predecessor, has some shortcomings.

We do not aim to study Draft Law No. 3405, so we will explore in short some of its provisions. In our opinion, given that there is an essential difference between the words "dispute" and "conflict" in the etymological sense between the words «dispute» and «conflict", it would be appropriate to use the word "dispute" in the text of the normative act. This would correspond to the normative documents of the European Union [1; 2] and of the United Nations Organization (hereinafter referred to as the UNO) [12].

In our opinion, the restriction to the use of alternative means of dispute resolution, including mediation, during pre-trial settlement of disputes (does not imply appealing to court) is not quite correct. In accordance with Art. 3 of Draft Law No. 3405, mediation may be applied in any conflicts (disputes) arising in civil, family, labor, economic, administrative legal relations, as well as in criminal proceedings during conclusion of reconciliation agreements between a victim and a suspect, the accused and in other spheres of public relations. It is also envisaged that mediation can be carried out before applying to court. However, given the changes envisaged to be made to the regulatory legal acts, the possibility of mediation is discussed solely upon the fact of appealing to court during 
the preparatory (preliminary hearing), the trial or after-trial proceedings. That is, the project does not provide for pre-trial settlement of a dispute without the need for an initial appeal to courts. The only exception is the resolution of labor disputes. In this case, it means the lack of the data on the possibility of using alternative means, including mediation, as a pretrial resolution of tax disputes with the bodies of the State Tax Service of Ukraine (hereinafter - the STS of Ukraine, controlling bodies) and the inclusion of the relevant norms by making amendments to the Tax Code of Ukraine [13].

The issue of professional skills and requirements for obtaining the status of a mediator is debatable. In our opinion, a mediator is a neutral person who acts as an intermediary, the so-called "peacemaker", whose efforts are aimed at resolving a dispute between the two parties. Of course, a mediator should not provide clarification or any advice on a dispute. However, in order to understand the causes of a particular dispute, to provide highquality assistance not only in its resolution, but also in trying to maintain proper relations between the parties to a dispute, he must have basic knowledge and experience in a particular field (of course it also implies the professional training of a mediator) and to outline the questions that the parties to a dispute need to be asked for their reconciliation. For example, in order to become a lawyer, a person must have the work experience in the field of law for at least two years [14].

The disputes that arise between two parties are more often related to determining and fulfillment of their rights and obligations, including the application of certain legal norms, so surely a mediator must be aware of the provisions of the current legislation. At the same time, when it comes to tax disputes (involvement of the Tax Mediation Service, which can be established in the regulatory authorities, to their resolution) a mediator should not necessarily have legal education. The STS bodies of Ukraine mostly employ people with economic education, however they have a rather high (decent) level of mastery of knowledge and skills of applying tax legislation, as well as understanding the problematic issues and contradictions that arise between regulatory authorities and taxpayers in the course of performing their rights and obligations. Therefore, the restrictions that a mediator cannot be a person, in particular, authorized to perform the functions of the state or local self-government, are incorrect. 


\section{Tax disputes}

In modern literature there are many ideas as for defining and understanding the concept of "tax dispute". Disputes in the tax sphere take a special place (they arise during performing the proper powers of the supervising bodies with the involvement of tax payers (physical or legal entities) in fulfilling the tax duties) due to disputing the corresponding tax act or its improper fulfillment. By content, tax disputes arise as a result of performing the executive activity by the body of the state tax service, rather than due to the implementation of the property rights, which is characteristic of civil affairs. The disputes that arise as for imposing administrative sanctions and making citizens responsible for tax obligation, though they are related to property consequences, but rather as a result of non-transition of material benefits to them, as well as unequal rights of the parties in such legal relations and differ from proprietary relations, regulated by the norms of the civil, family, labor law, etc. [15].

A tax dispute is determined as a material protective legal relations that arise between the entities of tax legal relations as for the disputes about one's own rights and obligations and/or legitimacy of legal acts of controlling (fiscal) organs, which are related with the implementation of tax and legal norms, and which are resolved in the order established by law. The structural elements of a tax dispute are its parties, subject and the ground [16].

Thus, tax disputes (the disputes between tax payers and controlling (fiscal) bodies) can arise in regard to (subject of a dispute): determining monetary obligations by the consequences of tax administration (control); appearance and payment of tax debt (installment and delay, deposit); other decisions, actions or non-action. That is, they can be proprietary (determining monetary obligations; imposing tax debt, etc.) or nonproprietary (administration of checks; nullifying registration of a added value tax payer or a unified tax payer; tax consulting; refusal to register tax invoice/ adjustment calculation, etc.); by they essence, they are related to the adoption of the relevant act (decision) of the individual action.

In many cases, the initiator of a tax dispute is a tax payer, who thinks that, having made the corresponding decision, the supervising body violates his rights, legitimate interests and/or has gone beyond its powers. In this case, it is not worth ignoring the factors that influence the arising a tax 
dispute. They can be internal (personal beliefs of a tax payer (individual legal awareness) as for the violation of his rights and legitimate interests; financial condition) and external (political and economic state; subjective and/or objective views (ideas, beliefs) of other people).

Currently, the condition of the possibility of resolution of tax disputes both in the trial and pre-trial order (administrative appeal) is legislatively regulated. The pre-trial resolution of tax disputes with the help of the administrative appeal of the resolutions of the controlling bodies implies the possibility of appealing to the superior controlling body with a complaint about the revision of the adopted resolutions and stipulated by the provisions of the Constitution of Ukraine [17], the Tax Code [13].

It should be noted that there are a lot of ideas about the effectiveness of the application by tax payers of the procedures of administrative complaint. In most cases, these are the ideas about low trust and ineffectiveness of the application of procedures of administrative appeal. In this case such conclusions are made exclusively on the ground of statistical data on administrative complaint, based on their number (in percent) of the resolutions that were complained of and the resolutions that were adopted in favor of tax payers (about satisfaction of complaints and canceling tax notifications-resolutions (resolutions).

We can not but agree with such arguments. Firstly: a low statistical percentage of the resolutions that were complained of or cancelled (satisfied complaints) do not testify to low quality or subjectivity (formality) of the procedure of administrative appeal (defending the interests of controlling bodies). Secondly: there are no data about the number of tax disputes that underwent the procedure of administrative complaining, and were subsequently resolved in favor of a tax payer as a result of consideration in court.

Besides, the application of the pre-trial (administrative appeal) of the resolution of tax dispute in Ukraine is of non-obligatory nature, which is why it is up to a tax payer whether to file a complaint of the resolution of the supervisory body, actions or non-actions of the latter. Along with this, in most countries the application of the procedures of the pre-trial (alternative) dispute resolution (filing objections, protests and complaints, performing mediation) is obligatory, only after going through them it is possible to appeal to court [18]. 


\section{Alternative dispute resolution: International experience}

In Ukraine, the possibility of applying alternative means (mediation) of resolving administrative disputes that include tax disputes, in which the party is the subject of power, is considered in the context of appealing to court (adoption of the resolution on its application at the previous meeting (before the proceeding), during the proceeding or after the proceeding is over (court mediation as a part of the court proceeding) $[6 ; 19 ; 20]$. This includes applying to the court, payment of the court fee (which will certainly be partially returned in case of successful mediation), payment for the services of a lawyer (in view of the fact that in accordance with the current legislation [17], a lawyer represents the interests in judicial instances). That is, it does not comply with the general principles of the use of alternative means of dispute resolution: reducing the burden on courts; access to justice (a decrease in financial losses of legal entities and individuals).

In the world practice, the pre-trial application of alternative means of dispute resolution, including mediation, between taxpayers and tax authorities is considered one of the most effective working methods of resolving disputes in tax relations. In relation to the international experience, we will focus on the practice of their application in such countries as the United States, Belgium and the Netherlands.

In the US, for dispute resolution, the Tax service offers a number of ADR programs aimed at resolving a case much earlier than the formal process of the Appeal to the Tax Service. The programs of ADR of the Tax Service, which use mediation, include the Quick Resolution Program (QRP), the Quick Mediation Program (QMP) and the Post-Appeal Mediation Program (PAMP). In particular, the QRP offers representatives of the small business and self-employed individuals the way of resolving disputes in less than 60 days, using the assistance of a tax service employee who was specially trained in mediation. In turn, the QRP and PAMP offer taxpayers and the Tax Service an opportunity to apply mediation with the participation of an official of the Appellate authority of the Tax Service, who acts as a neutral party. Unlike the QRP, in these programs, a tax officer has no delegated powers and will not make a decision on any disputable issues. The Appellate authority is an independent Tax Service department responsible for consideration of most disputes between taxpayers and the Tax Service. This program is not mandatory [21]. 
The procedures for tax mediation that take place in Belgium may be initiated only after the commencement of pre-trial (administrative) procedures for the resolution of tax disputes. To solve a particular tax dispute, an officer (mediator) of the Tax Service mediation is appointed, who is a person authorized to search for the most optimal and compromise decisions for the parties of a tax dispute. An officer of the Tax mediation service listens to both parties of a tax dispute, analyzes the actual composition of the case and offers the parties the options for resolving a tax dispute, which subsequently form the basis of the recommendation stated by a mediator. The content of the report of the Tax Service mediation consists of the comments (judgments of a tax mediator concerning certain actual circumstances that exist in a particular tax dispute) and recommendations (inferences, proposals of a tax mediator aimed at the resolution of disputed tax legal relations by searching for the algorithm for resolving the corresponding tax dispute that is the best for the participants of the reconciliation procedures).

The relevant body of alternative dispute resolution retains its full autonomy from the activity of the tax authority acting as a controlling institution in the field of taxation, the sphere of competence of which includes administration of generally compulsory payments. It should also be noted that in Belgium, in addition to the Tax Service Mediation, the Institute of Tax Ombudsman is also operating effectively. It is the Federal Commissioner who considers taxpayers' complaints. The sphere of competence power of the Tax Ombudsman includes decision-making, which have their focus to ensure the reconciliation of the parties to a tax dispute [22].

In the Netherlands, the alternative tax dispute resolution through mediation has been recognized since 2005. Thus, based on the results of the experiment on tax dispute resolution conducted by the Ministry of finance in some tax districts, a letter was published, according to which 75 cased passed through the mediation procedure during the year and $80 \%$ of cases had a successful resolution result. In case the agreement was not achieved (a failure), during an alternative dispute resolution, the parties had the right to apply to the court. Application of mediation while resolving tax disputes in the Netherlands is positively assessed by both parties of the conflict. The survey of the parties about the attitude to mediation shows that approximately $90 \%$ of the respondents say that in such cases they would 
prefer to pass through this procedure again, and not appeal to the court. The same is admitted by $67 \%$ of tax inspectors. As a result of conducting the mediation procedure, a protocol-agreement is drawn. An additional argument in favor of mediation is the fact that the service offered by the Tax Service mediation for entities is free and it is funded by the budget. The main argument in favor of mediation in administrative cases is the data of the Dutch Experts that in each case, to which mediation procedure is applied, the State saves on average from 20 to 50 thousand EUR [20].

As we can see, alternative means of resolving tax disputes are widely applied in tax disputes between taxpayers and tax authorities from different countries as pre-trial dispute resolution (implies preliminary appeal to the tax authority). In some countries, the pre-trial dispute resolution procedure (application of alternative means) is obligatory, as only after going through it, it is possible to appeal to the court. In most cases, the procedure of applying alternative means of dispute resolution has the form of intermediation, rather than mediation (in an appropriate sense), and is reduced to the adoption of compromise decisions (recommendations) solely by the relevant competent Tax authority.

There is also a practice of publishing newsletters by tax authorities, which refers to taxpayers' opportunities to use the alternative means of dispute resolution. In addition, they specify a list of cases, in which alternative dispute resolution tools may be used [23;24].

\section{Alternative dispute resolution: Tax compromise}

In our opinion, alternative means (mediation) of tax dispute resolution in Ukraine as a separate permanent institution, especially in the pre-trial dispute resolution (presumes a preliminary appeal to the supervisory authority), has the right to exist and to be introduced. According to the results of such measures, depending on the type of dispute (proprietary (existence of a predetermined monetary obligation and/or tax debt) or nonproprietary (other decisions, actions or inaction), recommendations can be provided and decisions on reconciliation and/or a tax compromise, such as the one stipulated by the Law of Ukraine On the procedure of repayment of taxpayers' obligations to budgets and state target funds, are made [25]. In addition, tax compromise, as well as reconciliation, may also be applied during the litigation of tax disputes. 
At the same time, such tax compromise should not be confused with the tax compromise that was stipulated by sub-section 92 of the Chapter XX "The transitional provisions" of the Tax Code [13] and was of temporary character and concerned the so-called «tax amnesty» (tax payer's agreement to pay a part of the amount that was determined in the tax notification-decision or in the adjustment calculation). Its introduction is more similar to defending the interests of certain financial groups. In view of that, it is impossible to agree with the statement that the achievement of a tax compromise (the corresponding institution) is determined by the possibility of any taxpayer who seeks to legalize its income, to appeal to such institution [26].

We believe that the application of a tax compromise is reasonable during the resolution of the controversial tax legal relations between a taxpayer and the supervisory authority, regarding their rights and obligations, in the event that the available legal facts about the circumstances of the case are insufficient to conclusions on legality of the behavior of a taxpayer or the supervisory authority. That is, the possibility of making a compromise decision in the situation where the evidence provided by the parties of a tax dispute is insufficient for unambiguous conclusions about the actual circumstances that determine the legitimacy of their behavior. In addition, the tax compromise may be considered not only as a means of settlement of discrepancies, but also as a mechanism for decreasing the burden on a taxpayer on payment of tax liabilities if such payment may lead to deterioration of his property state and termination of economic activity (reduction of tax revenues to the budget in the future) as stipulated by the Law of Ukraine "On the procedure of repayment of taxpayers' obligations to the budgets and State target funds" [25].

The concept of the tax compromise may be defined as a mutually approved agreement issued in writing, between the Fiscal service authority and a taxpayer within the procedure of alternative dispute resolution (mediation) during administrative (pre-trial) and/or judicial appeal based on mutual concessions regarding their rights and/or duties determined by the norms of current legislation on administration (collection) of taxes (fees, payments) and other legislation, the control over which is entrusted to the bodies of the fiscal service. The mentioned written agreement is not subject to further appeal, but provides for the possibility of its enforcement by a court decision. 
At the same time, the application of alternative means of dispute resolution (in case of a failure to achieve reconciliation or tax compromise) does not limit the taxpayer's rights to resolve a dispute in court.

The issue of legal personality of the parties to the dispute, in particular the subject of power, remains controversial at present, as fiscal service authorities in a certain sense are limited in choosing a variant of behavior in view of the fact that they should act within and in accordance with applicable law.

In our opinion, alternative means of dispute resolution (mediation) and their consequences (reconciliation and/or tax compromise) may not be applicable to tax disputes related to:

- criminal liability;

- certain issues, in respect to which there is no litigation practice;

- rendering individual and/or generalized tax consultations.

It is appropriate to use the alternative means of resolving tax disputes (mediation, intermediation) in the resolution of tax disputes relating to:

- issues related to the suspension of registration of VAT invoices/ adjustment calculations and decision-making on refusal in their registration in view of the impossibility of confirmation or refutation of the presence of certain documents, due to the inability to open them for viewing by the controlling authority (damage);

- application of penalties for violation of the terms of registration of tax invoices/ adjustment calculations not through the fault of a taxpayer, but in connection with the imposition of arrest on the electronic accounts of a payer in the CEA of VAT, technical problems that affect the impossibility of timely registration.

Given the experiment conducted by the Ministry of Revenues and Duties of Ukraine in 2013 [27] and the positive experience of extrajudicial dispute resolution (reconciliation), mainly without the involvement of third parties (exclusively bilateral communication "taxpayer - controlling authority"), the introduction and the use of alternative means of resolving tax disputes, including mediation (in a slightly modified form), is possible by creating the appropriate independent subdivision (Tax mediation services) (full autonomy and independence on the activities of the supervisory authority) within the regional tax authorities (the Main STS departments in the regions) (without changing the total stuff quantity). The need for providing such subdivisions 
with the qualified specialists is possible due to the relevant subdivisions of pre-trial dispute resolution (availability of professional knowledge and experience with taxpayers (experience of communication within the framework of the procedures of pre-trial dispute resolution), knowledge of the specifics of tax disputes) and/or other structural subdivisions (including experience and having appropriate professional competence), to ensure quick and qualified dispute resolution. It is possible to be considered as an improvement of the existing pre-trial dispute resolution system as a component of tax administration.

In addition, we can agree with the opinion on the introduction of voluntary mediation without changing the current legislation at the level of laws, through the publication of the relevant subjects of authority (within their competence) of by-laws acts [28].

Taking into account the fact of signing the Association Agreement between Ukraine and the European Union [3], as well as the inclusion to the Plan of the actions on the implementation of best practices of qualitative and effective regulation, reflected by the World Bank Group in the methodology of the "Doing Business" rating [4], in our opinion, it would be appropriate to introduce the institution of alternative means (mediation) of tax dispute resolution as an experiment in certain regions (taking into account the specific of the activity, the number of tax payers and the number of tax disputes) at the level of regional bodies of the STS in the oblasts. There are possibilities of engaging professional mediators and conducting training (seminars) for the employees involved in the experiment. Conducting such an experiment would make it possible to determine: the shortcomings of introduction and, accordingly, the ways to solve problematic issues; to outline distinctly the legality of participants of such procedures (rights and obligations); the range of tax disputes, to which alternative tools of resolution can be applied, depending on the subject; required professional competence and the number of specialists of such units; volumes of material and technical maintenance (we consider the costs of creation will be negligible).

We should not exclude the possibility of involving third-party organizations (mediators) in order to implement alternative means of tax dispute resolution, but this will imply the payment for services for their implementation (of course, much less than the cost of payment of legal fees and services of a lawyer). 
A significant argument for the introduction of alternative means of resolving tax disputes (mediation) with the help of the departments of the State fiscal service, which in general will lead to the establishment of partnership relations between the supervisory authority and a taxpayer (improvement of tax administration), as well as saving of labor and material resources both of a taxpayer and the supervisory authority, are:

- timeliness, speed, objectivity and quality of resolution. The case is considered directly between a taxpayer and the supervisory authority through the mediation of officers of Tax mediation service, if there is full information about the circumstances of the case (tax dispute resolution can be made within 3-5 working days) without the need to spend time involving third parties. Fiscal service bodies are interested in establishing partnerships with taxpayers and filling up the state budget;

- no need for taxpayers to pay for such measures. The work of subdivisions is funded by the state budget in the form of a salary (it is also possible to provide additional funding (to improve the material and technical base), depending on revenues from the state budget due to the payment of monetary liabilities (tax revenues) by the results of measures taken);

- ensuring full confidentiality regarding the subject of a tax dispute and information relating to the relevant procedures. The supervisory authority (the SFS) is an administrator of information on the activities of taxpayers (including the tax dispute) and ensures its storage and protection. Information about the case of a taxpayer that the supervisory authority has is confidential and will be used solely for the purposes which are determined by the tax legislation;

- economy of budget funds. During the court proceedings of the taxpayer's claim, there is a possibility of making decision not in favor of the supervisory authority, which will involve the payment of the court fee, including for filing an appeal (cassation) complaint.

\section{Conclusions}

Thus, summing up the stated above:

1. When drafting and adopting the Law of Ukraine On Mediation (in our opinion, it is more appropriate to say On the Alternative Tools of Dispute Resolution), it is appropriate to take into account and eliminate all existing problematic issues and shortcomings, in particular: 
- to envisage the order of creation (termination) and activity of organizations (associations) of mediators (a form of the certificate of registration of an entity of a relevant activity);

- formation of the qualification commission, which will evaluate the activities of mediators (the order of work); determining professional requirements for mediators;

- to envisage the possibility of using alternative means during a pre-trial resolution of tax disputes (making amendments to the relevant normative act).

2. Alternative means of resolving tax disputes are widely used in tax disputes between taxpayers and tax authorities of different countries, in particular of the European Union, specifically, as pre-trial settlement of disputes (provides for preliminary appeal to the tax authority). In some countries, the procedure of pre-trial settlement of disputes (application of alternative means) is mandatory. It is possible to apply to court only after passing through it.

3. Tax disputes can be property or non-property disputes. In most cases, the initiators of a tax dispute are taxpayers, who believe that the controlling body violates their rights, legitimate interests, and/or goes beyond its powers by making the corresponding decision. The factors influencing the occurrence of a tax dispute can be internal and external.

4. In Ukraine, it is possible and expedient to introduce alternative means (mediation) of tax dispute resolution (making amendments to the relevant normative and legal acts) as a separate permanent institution of pre-trial resolution of disputes (preliminary appeal to the supervisory authority), which will include giving recommendations and making decision on reconciliation and/or a tax compromise. In addition, a tax compromise, as well as reconciliation, can be also applied during the trial of tax disputes. At the initial stage, the introduction of the institution of alternative means (mediation) of tax dispute resolution is possible as an experiment in certain regions at the level of regional bodies of the STS in the regions, involving professional mediators in arrangement trainings (seminars) of employees engaged in the course of the experiment.

5. The concept "tax compromise" can be defined as a mutually approved agreement issued in writing between the fiscal service authority and a taxpayer within the procedure of alternative dispute resolution (mediation) during administrative (pre-trial) and/or judicial appeal based on mutual concessions regarding their rights and/or duties determined by the current 
legislation on administration (collection) of taxes (fees, payments) and other legislation, the control over which is entrusted to the bodies of the fiscal service. The mentioned written agreement is not subject to further appeal, but provides for the possibility of its enforcement by a court decision.

\section{References:}

1. Recommendations No. (2001) 9 of the Committee of Ministries of the European Council to the countries-members of 5 September 2001 on the alternatives to court hearing the disputes between administrative bodies and the parties - individuals. Retrieved from: http://www.scourt.gov.ua/clients/vsu/vsu. nsf/6b6c1e2e6ad3e2fcc225745c0034f4cc/7442a47eb0b374b9c2257d8700495f8b/\$FILE/Рекомендація\%20Rec\%20(2001)\%209.pdf(accessed 01 October 2020).

2. Directive of the European Parliament and the Council No. 2008/52/EU of 21 May 2008 on the particular aspects of mediation in civil and commercial cases. Retrieved from: http://zakon3.rada.gov.ua/laws/show/994_a95I (accessed 01 November 2020).

3. On the Association between Ukraine, on the one hand, and the European Union, European Community on the atomic power and their countries-members, on the other hand: Agreement of 27.06.2014. Retrieved from: https://zakon.rada.gov.ua/ go/984_011 (accessed 01 October 2020).

4. Decree of the Cabinet of Ministers of Ukraine No. 1406-p of 16 December 2015 on approval of the action plan on implementation of best practices of high-quality and effective regulation, reflected by the World Bank Group in the methodology "Doing Business" for 2016. Retrieved from: http://zakon3.rada.gov.ua/ laws/show/1406-2015-p (accessed 01 November 2020).

5. Dobkowski J. Tax mediation in Poland: current status and perspective of changes. II International scientific and practical conference: Court proceedings of tax and customs disputes: problems, challenges, priorities (Kyiv, July 4-5, 2019): Collection of materials. Kyiv, $354 \mathrm{p}$.

6. Law of Ukraine No. 2747-IV of 6 July 2005 Code of administrative legal procedure of Ukraine. Retrieved from: https://zakon.rada.gov.ua/laws/ show/2747-15\#Text (accessed 10 November 2020).

7. Law of Ukraine No. 1798-XII of 6 November 1991 Economic Procedural Code of Ukraine. Retrieved from: https://zakon.rada.gov.ua/laws/show/ 1798-12\#Text (accessed 12 November 2020).

8. Law of Ukraine No. 1618-IV of 18 March 2004 Civil Procedural Code of Ukraine. Retrieved from: https://zakon.rada.gov.ua/laws/show/1618-15\#Text (accessed 12 November 2020).

9. Law Draft No. 3665 of 17 December 2015 on mediation. Retrieved from: http://w1.c1.rada.gov.ua/pls/zweb2/webproc4_1?pf3511=57463 (accessed 10 November 2020).

10. Law Draft No. 2706 of 28 December 2019 on mediation. Retrieved from: http://w1.c1.rada.gov.ua/pls/zweb2/webproc4_1?pf3511=67831 (accessed 10 November 2020). 
11. Law Draft No. 3504 of 19 May 2020 on mediation. Retrieved from: http://w1.c1.rada.gov.ua/pls/zweb2/webproc4_1?pf3511=68877 (accessed 10 November 2020).

12. Typical law of the Commission of the United Nations Organization on the law of the international trade. International document of 24 June 2002 on the international commercial agreement procedure. Retrieved from: http://zakon2.rada.gov.ua/ laws/show/995 117 (accessed 10 November 2020).

13. Law of Ukraine No. 2755-VI of 2 December 2010 Tax Code of Ukraine. Retrieved from: https://zakon.rada.gov.ua/laws/show/5076-17\#Text; http://zakon5.rada.gov.ua/laws/show/2755-17 (accessed 10 November 2020).

14. Law of Ukraine No. 5076-VI of 5 July 2012 on advocacy and lawyering. Retrieved from: https://zakon.rada.gov.ua/laws/show/5076-17\#Text (accessed 10 November 2020).

15. Buriak, S., Melnyk, P., Ruban N. and others (2009). Tax disputes: emergence, nature, ways of settlement. Buriak, S. ed. Iurinkom Inter. (in Ukrainian)

16. Kitsenko, V. (2015) Concept of a tax dispute as protective legal relations. European prospects, vol. 4, pp. 136-139.

17. Constitution of Ukraine of 28 June 1996. Retrieved from: https://zakon.rada.gov.ua/laws/show/254\%D0\%BA/96-\%D0\%B2\%D1\%80\#Text (accessed 17 November 2020).

18. Tsereteli, L. (2016) Mediation as an alternative resolution of tax disputes. Retrieved from: http://www.visnuk.com.ua/ua/pubs/id/90003283 (accessed 11 November 2020).

19. Biluga, S. (2015) Pre-trial settlement of administrative-legal disputes. Retrieved from: https://mydisser.com/ua/catalog/view/6/352/36974.html (accessed 11 November 2020).

20. Krasilovska, Z. Conditions of mediation application for settlement of disputes with public power bodies: national and international aspects. Theory and practice of state management, vol. 4(51), pp. 200-207.

21. Yeriomenko, G. (2014) Tax mediation: experience and prospects of implementation. Lawyer \& Law. Retrieved from: https://ukrmediation.com.ua/files/ Eremenko_Zaichenko_U\&Z.pdf (accessed 10 November 2020).

22. Kurylo, V. (2016) Belgian experience of implementation of mediation procedures in resolving tax disputes. The Journal of Eastern European Law, 34, pp. 97-103.

23. Alternative Dispute Resolution (2018). Retrieved from: https://assets.publishing.service.gov.uk/government/uploads/system/uploads/ attachment_data/file/701213/CCFS21.pdf (accessed 10 November 2020).

24. Fast Track Mediation - Collection A Process for Prompt Resolution of Tax Issues (2018). Retrieved from: https://www.irs.gov/pub/irs-pdf/p3605.pdf (accessed 8 October 2020).

25. Law of Ukraine No. 2181-III of 21 December 2000 on the order of paying liabilities of taxpayers to budget and state target funds. Retrieved from: http://zakon0.rada.gov.ua/laws/show/2181-14 (accessed 8 October 2020). 
26. Kurylo, V. (2017) Legal nature of procedures of resolving tax disputes: comparative-legal analysis. Retrieved from: http://phd.znu.edu.ua/page//aref/07_2017/ Kurilo_aref.pdf (accessed 13 October 2020).

27. Mediation in tax cases is able both to ensure achieving a mutually beneficial decision, and to contribute to filling the budget (2015). Retrieved from: http://zib.com.ua/ua/115612-keruyuchiy_partner_yuk_prove_group_v_kochkarov_mediaciya_v_p.html (accessed 14 October 2020).

28. Goloiadova, T. (2016) Necessity of legal implementation of mediation for resolution of tax disputes in Ukraine. Young scientist, vol. 8(35), pp. 74-79. 